Richard Oram

IRSS 42 (2017)

\title{
The Making And Breaking of a Comital Family: Malcolm Fleming, First EARL OF WigtoWn, AND ThOMAS FLEMING, SECOND EARL OF WigTOWN
}

\author{
PART 1
}

The MAKING OF AN EARL: MALCOLM FLEMING

\section{Richard D. Oram*}

Amongst the consequences of the invasions, civil and foreign wars, and political volatility which followed the death of King Robert I in 1329 was profound reshaping of the circle of military-political leaders upon whom Bruce power depended. Leaving aside extinction through genetic failure or battle casualty, the midfourteenth century is otherwise characterised by the brief efflorescence of families who rose from the ranks of the lower nobility into the upper echelons of the Scottish political community before fading back into obscurity. Through their failure to establish permanency within the inner circle of the magnate community, the careers of men who won temporary distinction have been largely ignored in narratives founded on sources like Gesta Annalia II, Barbour's Brus or Andrew of Wyntoun's Orygynale Cronykil of Scotland, which focussed on 'winners' like the Douglases and the Stewarts. That position changed significantly in the 1990s and early

* Richard Oram is a graduate of the University of St Andrews, where he gained his MA (Hons) Mediaeval History with Archaeology in 1983 and $\mathrm{PhD}$ in Mediaeval History in 1988. He joined the University of Stirling in 2002, where he is Professor of Medieval and Environmental History and, currently, Dean of Arts and Humanities. The first of his monographs, The Lordship of Galloway, was published in 2000; since then he has published extensively on medieval Scottish and North Atlantic environmental history, settlement and society, with a particular focus on lordship structures, resource exploitation and environmental change. 
2000s with a generation of revisionist historical research which opened new perspectives on the social and political structures of fourteenth-century Scotland. ${ }^{1}$ This work challenged traditional narratives to explore the dynamics of power as revealed in exchequer accounts, parliamentary records and charter texts and throw new light on the careers of men who occupied at best cameo roles in the chronicle accounts and whose families rose briefly to national significance in one generation to sink back into obscurity in the next. ${ }^{2}$

Amongst these mayfly-like figures who burst into prominence but who failed to establish a lasting legacy were the Fleming earls of Wigtown. The Flemings were a family who typified a new breed of lord; middle-ranking nobles who cannily positioned themselves to fill voids left by the magnate forfeitures and extinctions of the first Wars of Independence, but nevertheless creatures of the crown and utterly dependent on its patronage for their political, economic and social survival in the aristocratic top flight. The two parts of this present study (the second of which follows immediately after this one in the present volume) explore the careers of the two Fleming earls, Malcolm and Thomas, examining their personal and political relationships with the Bruce kings and exploring their interaction with the wider magnate community and with Robert Stewart in particular. Contemporary record evidence for even their immediate family relationships is fragmentary, and their limited surviving acts make it difficult to analyse the composition of their following or to make meaningful observations of their personal faith and devotional activity. Nevertheless, from what survives some broad observations on their network-building and religious behaviour will be offered.

It is impossible to determine what links, if any, connected the various families designated as 'Fleming' who were established throughout Scotland by the thirteenth century. Their geographical spread-from Aberdeenshire to Dunbartonshire and Clydesdaleand their presence in both urban and rural contexts suggest that multiple individuals who were perceived to be of generally Flemish origin were involved rather than a single man whose descendants had spread rapidly round the kingdom. For the present discussion, one important Fleming kin-group descended from an immigrant 
family of knightly rank introduced into Clydesdale by the kings of Scots in the mid twelfth century has been identified as the ancestors of the Wigtown line. ${ }^{3}$ From a core landholding around Biggar, this family's influence by the 1200s extended across the sheriffdom of Lanark and into the inner estuary zone of the Clyde. Despite longstanding family traditions which identify one Robert Fleming as Malcolm's father and founder of both the fourteenth-century Wigtown and Biggar Fleming lines, ${ }^{4}$ there is no surviving evidence for this relationship. A man of that name was listed in March 1290 amongst the barons who confirmed the Treaty of Salisbury with Edward I of England and who gave their consent to the marriage of the Maid of Norway to Edward of Caernarfon. ${ }^{5}$ Recent scholarship, however, has identified this Robert with the Aberdeenshire laird, Robert Fleming of Wardhouse in the Garioch, who was active from late in the third quarter of the thirteenth century. Given the absence of any territorial designation awarded to the treaty witness, it is unclear on what basis this firm identification has been made. ${ }^{6}$ Knowledge of this near-contemporary Robert Fleming may have been seized upon by nineteenth-century genealogists as a convenient provider of a connection between the family's unequivocally pro-Bruce credentials under Malcolm Fleming and the Bruce coup of February 1306/7: Robert, on no historical grounds, was portrayed as a participant in the slaying of John Comyn at Dumfries. ' Similar association with the 'patriotic party' in the Wars of Independence figures prominently in several family histories constructed from the seventeenth century onwards, and was designed to give a spurious antiquity to the status of the family and its tradition of loyalty to the crown. ${ }^{8}$ There is likewise no surviving record of any grant to him of Cumbernauld, which Fleming family history claimed was the reward for his consistent pro-Bruce stance after $1306 .{ }^{9}$ All told, it appears that a Brucesupporting 'Robert Fleming' is a fiction created to add depth to the Flemings' recorded ties to the Bruce kings, manufacturing an association with the royal line that pre-dated the Bruce coup d'état.

An intriguing possibility for an alternative origin of a Bruce/Fleming tie is Sir Nicholas Biggar, lord of the same, descendent of the mid-twelfth-century Flemish lord of Biggar and a major landholder in Clydesdale. Nicholas was likewise a witness to 
the 1290 treaty but also possessed a political connection which could provide the basis for Malcolm's later association with King Robert. On 19 April 1290, Nicholas entered into an agreement with Robert Bruce the Competitor concerning the lands in the Garioch pertaining to the heritage of the heirs of David, earl of Huntingdon. ${ }^{10}$ In return for pursuing an action against other claimants to those lands-John Balliol and John Hastings-and, on the successful conclusion of that action, making them over to Bruce, Nicholas would receive 20 merks-worth of land south of the Forth from Bruce, to be held for the twentieth part of the service of one knight, described by Geoffrey Barrow as 'an almost nominal rent'. ${ }^{11}$ Little else is known of Nicholas and he appears to have died around 1292; there is no record of his submission to Edward I in 1296. Nicholas's unnamed heirs are mentioned in a Lanarkshire property inquest in 1302/3, indicating the continued importance of this family locally. ${ }^{12}$ There remains, however, no explicit link between Nicholas and the Wigtown and Biggar Flemings.

According to post-medieval family tradition, Malcolm Fleming, the future earl of Wigtown, was 'Robert's' elder son; his younger son, Patrick, established the Biggar line which gained headship of the family in the later fourteenth century; modern scholarship has been unable to confirm either link. ${ }^{13}$ An early connection to the Bruces may be reflected in traditions recorded in the eighteenth century concerning Malcolm's wife, Marjory, who was identified as a daughter of the pro-Bruce Sir Simon Fraser of Oliver Castle in Tweeddale. ${ }^{14}$ It was perhaps via that bond that Malcolm entered the upper echelons of noble society with the grant from Robert I of the substantial lordship of Kirkintilloch or Lenzie, which had been forfeited by John Comyn. ${ }^{15}$ The enrolled great seal charter recording this grant gives no indication of why Malcolm received this grant but his subsequent career indicates that he enjoyed a relationship with Robert I that was close and personal rather than simply political. Malcolm also emerges at this time as a Stewart associate, receiving a landholding from them in Kyle and in 1321 the gift of an annuity from Walter Stewart. ${ }^{16}$ The earliest datable evidence for Malcolm's association with the Stewarts is a charter of 1316 to which Malcolm was a witness. ${ }^{17}$ The connection was maintained with Walter's son, Robert, whose foster-father he 
became, and with whose guardian, Sir James Stewart of Durisdeer, he was associated following Walter's death in $1326 .{ }^{18}$ In the 1330 s and 1340s, these bilateral connections placed him in the advantageous position of being both a member of the inner circle of royal councillors down to David II's capture in 1346 and also an associate of Robert Stewart, David's nearest male heir and lieutenant during his captivity. It was a position that probably served Malcolm well until c.1340, but as the already unhappy relationship between David II and Robert Stewart deteriorated after then, it perhaps contributed longer term to his political eclipse. The breaking of the positive relationship between the king and the Flemings, however, came after a long and fruitful career in royal service.

Like several men of baronial rank who gained entry into the upper tiers of the aristocratic community, Malcolm's rise was founded on service that probably dated from the immediate aftermath of the February 1306 coup for him to have benefited so significantly from the redistribution of property that followed Bannockburn. One of the imperatives driving King Robert's policy in this regard was the need to reward men who had supported his cause, but it was equally important to bind these men into the regime construction embarked upon by the king and his close circle of supporters, to serve as agents of that new regime in the localities. Malcolm's chief gain was the barony of Kirkintilloch or Lenzie, held by the Comyn family from $c .1200$ and one of the nodes of that family's landholding and jurisdictional complex in the lower Clyde basin. ${ }^{19}$ As lord of Lenzie, Malcolm entered into new relationships of superiority over former Comyn tenants, amongst whom were the Carrick-based Kennedys who had held the office of steward for Kirkintilloch/Lenzie by $c .1260 .{ }^{20}$ It has been argued that Fergus Kennedy had probably received land there as part of his fee for his office and in 1296 one Hugh Kennedy was entered in Ragman Roll as holder of lands in neighbouring Lanarkshire. ${ }^{21}$ Despite their traditional association with Carrick and the consequent assumption that that placed them naturally in the Bruce camp from 1306, these Kennedy ties with the Comyns of Badenoch makes the alignment of their loyalties more questionable. Hector MacQueen suggested that the main period of ambivalence was post-1329 on account of 
the grant to Malcom Fleming in 1358 by King David II of lands in the barony of Lenzie that had been forfeited by John Kennedy, ${ }^{22}$ but there is no indication in Robert I's charter to Malcolm of when the forfeiture had occurred or for what reason. The surviving document was issued in 1315 but Malcolm possibly received title soon after 1306 when Robert was asserting his authority in areas of strong pro-Balliol loyalties. The earlier date would place the grant to Malcolm in the context of the Kennedys' delivery of Loch Doon Castle and Bruce's brother-in-law into English hands. ${ }^{23}$ Although Robert granted a remission of his rancour by 1308 or 1309 to Gilbert of Carrick, the then head of the Kennedy kin, some properties of the wider kin-group had perhaps been given by Robert to others whose loyalty at that time mattered more than that of a family whose faithfulness remained suspect. ${ }^{24}$

Malcolm's regional standing expanded later in the 1320s through acquisition of Auchindonan in the Lennox. ${ }^{25}$ Implicit within this landed power-base for Fleming was the enhancement of the Bruce regime's local leadership within the Dunbartonshire/ Lennox area. His regional role, however, was signalled as early as March 1315 when at Dumbarton he witnessed Robert's confirmation of the sanctuary privileges of St Kessog's church at Luss, accompanied by Walter the Steward, his kinsman John Menteith, James, lord of Douglas, Robert Keith and the important royal official and burgess of Dumbarton, Adam son of Alan. ${ }^{26} \mathrm{~A}$ similar regional grouping occurred in January 1327 at Perth when the Steward, John Menteith and Malcolm witnessed a royal charter giving Adam son of Alan land in Cardross to support a chaplainry in Dumbarton. ${ }^{27}$ Such fleeting appearances with the leading lords of the inner Clyde estuary zone hint at Malcolm's inclusion in Robert I's reconfigured post-1314 regional power structure, but his centrality to it emerges clearly only in the later 1320 s.

Although he is not so styled in the 1327 Perth charter, the meeting at which it was issued was perhaps when Malcolm was appointed sheriff of Dumbarton. He was in office certainly before February 1327 when he is first styled sheriff and keeper of Dumbarton Castle. ${ }^{28}$ Both positions had been held previously by Malcolm, earl of Lennox, a staunch Bruce loyalist. Under the terms of his 1321 grant of Lennox and the sheriffdom of Dumbarton to 
Earl Malcolm, Robert had to pay 500 merks annually to compensate Lennox for his loss of office, ${ }^{29}$ a cost which underscores Fleming's political capital at this time. Together with Kirkintilloch, and Kilmaronock at the south-eastern end of Loch Lomond attached to the keepership of Dumbarton, ${ }^{30}$ possession of the sheriffship and a castle regarded as a key stronghold of the kingdom made Malcolm one of the chief men in the territories around Glasgow and the inner Clyde estuary. As an immediate neighbour of the Stewarts' lordship of Renfrew and already possessing strong bonds with the Stewarts, this also made him a man to be courted by that family.

More frequent appearances as a charter-witness followed Malcolm's 'arrival' amongst the regional political leadership. It was as a lord with both Clydesdale and Ayr interests that on 7 May 1327 he witnessed a property transaction concerning an annual rent in Lanarkshire and its use to endow a perpetual chaplainry at Ayr. ${ }^{31}$ More clearly arising from his office as sheriff was his presence as first witness to a charter, datable only to $1327 \times 1333$, granted by Malcolm II earl of Lennox confirming Malcolm of Luss in possession of his heritage. ${ }^{32}$ His embedding into the local power structures is clearest during the later $1340 \mathrm{~s}$ and $1350 \mathrm{~s}$, by which time he had been elevated to the earldom of Wigtown; Malcolm regularly acted as the first named witness to acts of Earl Malcolm's son, Earl Donald, concerning properties throughout the Lennox. ${ }^{33}$ As sheriff from the late 1320s and deploying the jurisdictional weight of that role, Malcolm embedded himself into the social and political leadership of the south-eastern districts of the Lennox.

Malcolm's second area of regional influence was Carrick and western Galloway. His direct interest there began with a grant in $1327 / 8$ of property at Polton in Wigtownshire ${ }^{34}$ but his local presence stemmed from his management of the south-western lordships formerly held by Edward Bruce. From February 1327 until at least January 1330 Malcolm was bailie and steward of Carrick, ${ }^{35}$ an earldom whose strategic significance and political symbolism for the Bruce family broadcasts Malcolm's standing within the regime. Carrick had been granted in 1313 to Edward Bruce to provide him with a comital title and the territorial lordship commensurate with his status as a royal sibling and, at that date, 
sole male Bruce heir. ${ }^{36}$ It had been a secondary addition to Edward's regional powerbase, his primary possession being Galloway whose conquest between 1310 and 1312 he had spearheaded. ${ }^{37}$ As a centre of Balliol and Comyn partisanship during the Scottish civil war after 1306, the substitution of the leadership those families held in Galloway by that of a member of the new royal family was essential. Undermined in 1315 by Edward's diversion towards Ireland, the scheme failed upon his death in 1318. Although some Galloway lands were later granted to Edward's bastard son, Alexander Bruce, Carrick reverted to King Robert, who later bestowed it on his infant son, David, as a means of supporting the child's independent household. ${ }^{38}$ David was housed in Carrick's caput at Turnberry, with Malcolm as his 'foster-father' overseeing the administration of the child-earl's household and estates and care of the boy entrusted to Malcolm's wife, Marjory. 39

Although his other duties as sheriff of Dumbarton probably kept him regularly away from Carrick, Malcolm made diligent efforts to consolidate his position there. He won the adherence of several key men in the earldom who had been prominent in Edward Bruce's following, most notably Gilbert of Carrick, John of Knockdolian and his son, Nicholas, and Robert Wallace, who remained close associates until the end of Malcolm's political career. ${ }^{40}$ Wallace's connection with Malcolm possibly pre-dates the Carrick link, for he was constable of Dumbarton from perhaps as early as 1325 and was undertaking building work there in $1329 .{ }^{41}$

The connection with Carrick furnished Malcolm with the reservoir of military manpower upon which his status as a leading figure in national politics through the 1330s and 1340s depended. Alongside this emergence as a regional magnate with a military following of significance, however, Malcolm's political influence was being underscored through his appointment to a key office in the king's inner administrative circle; from 20 February 1328 until shortly after Robert's death in June 1329 Malcolm was steward of the royal household. ${ }^{42}$ His rise, however, was more than a reward for administrative aptitude. His guardianship of the king's heir signals a bond which speaks of loyal and long-standing service that was recognised and valued. It goes too far to suggest personal 
friendship, the relationship remained that of lord and servant, but Robert clearly identified in Malcolm a man on whom he could place the greatest trust. Of the gifts made to him in this final period of Robert's reign that which provides the clearest indication of this position was the contribution towards the costs of Malcolm's son's marriage, of which he received a part-payment of $£ 40$ in $1329 .{ }^{43}$ We know neither the name of the groom ${ }^{44}$ nor the identity of the bride, but the expenditure on the wedding suggests that it was a splendid event that reflected Malcolm's standing in the king's eyes.

There is only circumstantial evidence for Malcolm's activity between Robert's death in June 1329 and July 1333, but his record of royal service makes it likely that he remained prominent in the council of the three successive guardians of the kingdom during that period. He continued to discharge his duties as sheriff, it being surely in this capacity that at Dumbarton he witnessed a charter of Malcolm, earl of Lennox, ${ }^{45}$ but there is no explicit record of his political activity in this period. There is likewise no evidence that he was present at Dupplin in August 1332 but he did join Archibald Douglas's catastrophic attempt to relieve Berwick the following summer. He was reported to have been at Halidon Hill in the second division of the Scottish army that was nominally under the command of Robert Stewart. ${ }^{46}$ His presence in that division, which had a strongly Menteith, Clydesdale and Clyde estuary composition, reflected Malcolm's regional status but it also highlights continuing associations with the Stewarts. One of the few members of the pro-Bruce Scottish leadership to avoid the carnage on 19 July 1333, Malcolm escaped to Dumbarton Castle, which he held thereafter for the Bruce cause. ${ }^{47}$ With him were David II and Queen Joan, who perhaps had been moved there from Turnberry as early as autumn 1332. They remained in his charge until May 1334, when he secured their safe passage to refuge in France. $^{48}$

Although a naturally strong fortress, Dumbarton was not unthreatened and the chevauchée led by Edward Balliol that penetrated Clydesdale, Renfrew and Ayrshire in SeptemberDecember 1333 highlighted its exposure. ${ }^{49}$ On route, Balliol paused at the nominal heart of Stewart power, Renfrew, which he had already granted along with the Stewartry lands to David of 
Strathbogie, earl of Atholl. ${ }^{50}$ According to Andrew Wyntoun and Walter Bower, it was there that Balliol (but in this context more probably Atholl) received the keys of Rothesay and Dunoon, the principal Stewart strongholds in Bute and Cowal, which signalled the surrender of those areas into his hands, 'for nane durst hym contrary'. ${ }^{51}$ Who made this symbolic delivery, however, is not recorded. Balliol appointed Sir Alan Lyle, a man with strong Stewart links as well as Lennox and Menteith connections, ${ }^{52}$ as his sheriff in Bute and Cowal and gave Thomas Wooler a lieutenancy over the Renfrew and Kyle parts of the Stewartry. ${ }^{53}$ Wyntoun adds that before the end of the year Atholl had passed through all of the Stewartry lands and taken homage and fealty from the principal tenants. ${ }^{54}$

Traditional narratives of the late 1333 -early 1334 period are problematical, not least in disentangling the reality of Robert Stewart's actions from his semi-mythical role in the fight-back against Edward Balliol and his English ally that dominates fifteenth-century narratives. ${ }^{55}$ The over-running of the Stewart lordship and the part played by the young Steward in recovering his heritage is omitted from Gesta Annalia but appears in an extended form in both Wyntoun and Bower, who share a common lost source. ${ }^{56}$ According to both, while Balliol and Strathbogie were receiving the submissions of the Stewartry and its tenants, Robert was a passive onlooker from his refuge on Bute. There, he had frequent conversations with John Gilbertson and William Heriot, the former described by Wyntoun as a 'good man' and both by Bower as 'faithful to the king of Scotland' [David II]. Both chroniclers agree that they arranged Robert's transport to Inverkip on the mainland and from there overland to a point on the Clyde opposite Dumbarton, across to which he was conveyed in a rowing boat. ${ }^{57}$ Heriot cannot be identified but Gilbertson is likely the man recorded as bailie of Bute in $1329,{ }^{58}$ which would place him in a position of local influence and trust within Stewart administration.

As both Wyntoun and Bower agree that the keys of Rothesay had been delivered already to Balliol by some unknown hand, the question to be asked is had the young Steward attempted to treat with the new regime and sent the keys as a token of his submission? There is reason to believe that in 1335 when tensions 
between John Randolph, earl of Moray, and Robert brought a breakdown in co-operation between them that Atholl negotiated a deal for Robert to enter Edward Balliol's peace and retain his heritage. ${ }^{59}$ That manoeuvre displays remarkable self-preserving pragmatism-if not cynicism-on Robert's part and it is not unthinkable that he attempted to follow a similar course eighteen months earlier in 1333. Certainly, in the shocked aftermath of Halidon Hill, he was not the only Bruce loyalist to do so. The repeated conversations with Gilbertson and Heriot perhaps intensified as it became clear that Atholl in the closing months of 1333 was intent on taking possession of all that Balliol had given him. Realisation by the teenage Steward that there was no place for him in a Balliol political settlement forced him into the only alternative; resistance in the name of David II with Malcolm Fleming at Dumbarton.

While those events had been unfolding, Malcolm had been performing manoeuvres of his own. As one of the few leading Bruce partisans remaining, Malcolm was negotiating with Edward III through the closing months of 1333. Edward had succeeded in installing Balliol on the Scottish throne and many Scots, including Bruce loyalists like Fleming, might have been prepared to accept that result provided a settlement could be reached that secured their personal positions and provided for David Bruce. Such pragmatism, however, was overturned by Balliol's negotiations for payment for Edward's military support of his cause; this concluded with the transfer in February 1334 of much of southern Scotland to the English king. ${ }^{60}$ On 20 November 1333, in the midst of these negotiations, Malcolm received two safe conducts to come to England with his retinue 'on the king's (Edward III's) affairs' ${ }^{61}$ No record survives of what business was to be discussed or if the meeting ever took place but given Balliol's proposal to Edward III in February 1334 that he would marry the English king's sister Joan, described only as 'affianced' rather than married to David II, and to make provision for David within his kingdom, ${ }^{62}$ both issues that directly affected Malcolm as guardian of the two children, it is possible that his negotiations had been seeking to salvage something from the wreckage for David Bruce. Failure to secure 
acceptable terms presumably accelerated plans for the withdrawal of David and Joan to France.

Robert Stewart's presence at Dumbarton provided Malcolm with a means to open up the route to safety for his young charges. The late winter of 1333-4, according to Wyntoun and Bower, was spent preparing to recover the Stewart castle at Dunoon, whose proBalliol garrison controlled the entry to the inner firth of the Clyde and Dumbarton. ${ }^{63}$ Probably in April 1334, with men and ships provided by Dugald Campbell of Lochawe, Robert re-took Dunoon. News of that success triggered a rising on Bute, where the Balliol sheriff, Lyle, was slain and John Gilbertson, who was by that date evidently in Balliol/Atholl service, was captured. Gilbertson, who was 'captain of the castle of Bute', was forced to surrender Rothesay to them and then performed homage to his former lord. ${ }^{64}$ By early May, the northern and western sides of the Firth had been cleared of Balliol-held strongholds and Robert was beginning to push into his ancestral heartland in Renfrew. ${ }^{65}$ It was around that time that a French vessel reached Dumbarton to convey David and Joan to safety. There is no precise date for the voyage: all mention of it is omitted from Gesta Annalia, Wyntoun and Bower, but the continental chronicler Jean Froissart indicates that the crossing was made probably in the third week of May with an arrival in Normandy around 22 May. ${ }^{66}$

For the Bruce cause, the taking of the Balliol/English-held castles at the northern end of the outer Firth of Clyde not only secured the route by which David II could be carried to safety but also opened a channel through which French money and arms could be brought into Scotland and direct communication could be maintained with France and the papacy. Dumbarton, indeed, became the principal entry-point for supplies and personnel. It was there in 1334, for example, that John Randolph, earl of Moray, landed on his return from his embassy to King Philip VI of France. ${ }^{67}$ It is likely, too, that Dumbarton was the landing-place for Sir William Douglas and his company of French knights who arrived in Scotland in early summer $1339 .{ }^{68}$ The strength of the castle and its significance as the port-of-entry for men, money and equipment throughout this phase of the war probably accounts for its role as the main base for Robert the Steward's military 
operations down to 1341 and its continuing importance in an identical manner for David II after his return from exile.

There is no evidence that Malcolm accompanied David and Joan to France and he is not named amongst those who formed the king's court-in-exile, but there is otherwise little firm evidence for his presence in Scotland in the next six years. ${ }^{69}$ From 1334, Robert used Dumbarton Castle as his base, presumably assuming control as David's lieutenant and heir presumptive. A late tradition claims that he installed his own keeper in place of Malcolm. ${ }^{70}$ Certainly, accounts of John Randolph's meeting there with Robert Stewart in summer 1334 make no reference to Fleming. ${ }^{71}$ Of course, Wyntoun and Bower's source was concentrating on the two most important men in terms of status and the narrative of their encounter is focused on their likely joint lieutenancy for David II. We can also suspect, however, that reference to Malcolm has been expunged from both accounts that chose consistently to emphasise Robert Stewart's unflagging leadership in the counter-offensive against the Anglo-Balliol position, probably because by the date of their composition his lineage was extinct. There are, however, residual 'ghosts' in the texts which hint at an originally wider discussion of the progress of the pro-Bruce Scots' fight-back from Dumbarton. Wyntoun, for example, distinguished in his account of Robert's recovery of the south-west mainland between the men in his force who were 'his', i.e. came from his ancestral lands, and those that he found at Dumbarton. ${ }^{72}$

Robert Stewart's domination of these chronicle narratives of the recovery of the western districts of the kingdom from AngloBalliol control excludes almost all reference to other agents in that process. $^{73}$ It is important, however, to recognise that it was Fleming's retention of Dumbarton in 1333 which prevented Balliol's adherents from establishing complete control of the Stewart lands, despite Robert Stewart's flirtation with defection to the Balliol cause. It was Malcolm, furthermore, who secured the western midlands of the kingdom as a base from which the Bruce party could regroup and threaten their opponents' position in Clydesdale and Lothian. Indeed, it could be argued that it was his decision to remain loyal that prevented the terminal collapse of the Bruce kingship. Military leadership in the field was left to the 
surviving members of the senior nobility of the Bruce regime, such as Andrew Murray, John Randolph and Robert Stewart, but it was the steadfast allegiance of a handful of men like Malcolm Fleming that ensured that there was a Bruce cause to fight for and the fortresses to fight from.

Malcolm only reappears in the historical record as a witness to an inspection of a charter made at Dumbarton on 8 May 1340 by a panel presided over by Robert Stewart as lieutenant for David II. ${ }^{74}$ If nothing else, this act locates Malcolm still at Dumbarton and forming part of a group of men working under Robert's leadership. Consequently, it placed him in the advantageous position of being a bridging figure between the courtin-exile of David II at Château Gaillard and the king's lieutenant in Scotland, the Steward.

As emerged in the weeks immediately following David's return to Scotland in May 1341, Malcolm was held in high regard by the teenage king and was in regular attendance on him. This closeness stemmed from the role as David's foster-parents and guardians which the Flemings had discharged down to 1334, a role that was alluded to in subsequent royal gifts. It was surely political realities, however, rather than sentimental attachment that placed Malcolm amongst those who met David soon after his landing at Inverbervie and who formed a tight circle of councillors that traversed the country with David from June to September $1341 .^{75}$ Reward for his past service followed swiftly with a heritable grant in free warren of his baronies of Lenzie, Kilmaronock and Dalzell in Clydesdale. ${ }^{76}$ It is unknown when Malcolm had acquired Dalzell, it not having been in his hands by 1329. Kilmaronock, however, was royal rather than Lennox property and it was noted in the Exchequer accounts for 1329 that it was in Malcolm's possession for life for the keepership of Dumbarton; ${ }^{77}$ this 1341 grant now confirmed it as heritable property. Dalzell, which in the late 1360s lay within the lordship of Bothwell, ${ }^{78}$ had somehow been detached, probably after the death of Andrew Murray of Bothwell in 1338 when the Steward and his associates took possession during the minority of Andrew's heir. For Malcolm, these properties reinforced his leadership within the district extending from the southern end of Loch Lomond east through Strathkelvin and south 
into Clydesdale. It was upon this zone that he sustained his powerbase as a regional magnate.

On 18 July 1341 Malcolm was with David at Stirling, where the castle was under siege. There, he witnessed the king's grant of the earldom of Atholl, forfeited by the late David of Strathbogie, to William, lord of Douglas. ${ }^{79}$ The king had multiple aims with this award, seeking in the first place to bind Douglas, one of the most prominent and successful warlords of the previous seven years, firmly to him, and through him to gain access to Douglas's formidable military retinue. As earl, moreover, Douglas could mobilise Atholl's military resources and bind more firmly into Bruce control a territory where loyalty to the Strathbogies remained strong. Robert Stewart was invisible in these events and the grant to Douglas of Atholl, where the Steward had territorial ambitions, was a deliberate thwarting of those aspirations by the king. David's careful involvement in the process of men like Fleming, who had close links with the Steward, was designed to separate them from Robert's circle of associates. The teenage king was giving notice that he intended to resume control of royal patronage, long usurped by his nephew, and through that to build the network of loyal followers necessary to deliver the military resources that he required to restore the prestige of his kingship.

From Stirling David headed west to Dumbarton, where he may have re-established Malcolm's keepership of the castle. Certainly, it was as 'our foster-father (alumnus) and keeper of our castle of Dumbarton' that Malcolm was styled in royal letters patent probably issued at that time. ${ }^{80}$ It is unknown if he accompanied the king on his brief foray into Northumberland in late August, but he was with David in mid-September for his first full parliament at Scone, which Robert Stewart could not avoid attending. ${ }^{81}$ There, Malcolm was in David's inner circle of councillors, acting as a witness to all bar one of the surviving charters issued at Scone. ${ }^{82}$ From there David moved to Lanark and on to Ayr and Carrick, where he was based from at least 9 to 11 November, ${ }^{83}$ and from where it may have been intended to strike into Balliol's Galloway heartlands. It is probably no coincidence that it was at Ayr, where the strength of Malcolm's local following was most in evidence, that David gave formal recognition to him of 
his loyalty through the crisis years after 1333. The intentions behind the grant on 9 November 1341 of the lands of the sheriffdom of Wigtown, to be erected into an earldom entailed on Malcolm and his direct male heirs, and his creation as earl of Wigtown with rights of regality and special judicial powers, are unquestionable. ${ }^{84}$ This was a very personal grant, limited to Malcolm and direct heirs of his body, with the entail thus preventing potential future devolution onto collaterals like his Biggar kinsmen. Entails of this kind were still a novelty in Scottish inheritance practice and the use of this device in the award to Fleming is perhaps indicative of awareness already among David and his councillors of the precariousness of the future male descent of the family. Such an arrangement preserved the future integrity of the Fleming heritage in Galloway against the threat of its partition between Malcolm's adult daughters and their husbands. David was not creating a new earldom to provide leadership and control in a still-fractious territory simply for it to fragment in the hands of men who lacked the status or landholding to maintain that domination. The first witness to the grant was Robert Stewart, who was not yet himself the holder of a comital title and who was surely left in no doubt that this elevation of his social inferior was a signal of David's intention to continue to dismantle the power-base that the Steward had built over the previous seven years. David made it clear that the military leadership of a region where the Steward had displayed ambitions to extend his authority would be exercised by a man of his making, not the Steward's. If Malcolm had any lingering ties to Robert, this act was intended by David to sever them and give the crown its loyal strongman in Galloway.

There is no evidence that Malcolm accompanied David as he moved northwards again, ceasing to witness any royal charters between 11 November at Ayr and 16 February 1342. It is likely that he had spent some of this time in western Galloway seeking to convert his parchment patent into a reality. He had, however, rejoined the travelling court by 14 February for what proved to be a tense and ultimately humiliating gathering at Aberdeen. There, William Douglas and Robert Stewart joined forces to reverse various aspects of David's land grants made since the previous June, ${ }^{85}$ exposing the fragility of the king's grip on real power and 
authority. This was most obvious in his lack of command of significant military resources and the still largely paper titles upon which was founded the status of the men whom he was seeking to build into the core of a personal following.

Malcolm was one of David's paper tigers whose position was more titular than real. Within his earldom, Malcolm's demesne was intended to comprise of the burgh of Wigtown, his nominal caput or 'principal manor-place' as the charter styled it, and all royal lands throughout the sheriffdom, which consisted chiefly of the heritage of Alexander Bruce which had reverted to the crown after Halidon Hill. These lands are not listed in detail but, based on the named demesne properties in the earldom of Wigtown forfeited by the Douglases in 1455, they comprised a cluster of estates in the central Machars district of Wigtownshire with a scatter of outlying lands in the northern Moors area and in the Rhins. ${ }^{86}$ It was hardly a dominating landholding and, as with the Randolph earldom of Moray, it was not on a superior landed position that Malcolm's power as earl depended but on a jurisdictional franchise, the delegated royal powers represented by the king's grant of a free regality.

But the jurisdiction would only be effective if Malcolm could impose his lordship over western Galloway and to do that he needed to establish military control. That seems to have been achieved in part through the warbands of the Carrick-based men in his following, but he still needed access to the network of regional kinship ties that had given substance to the authority the lords of Galloway in the pre-1300 era. ${ }^{87}$ Malcolm faced the entrenched power of that network in the MacDowell kindred, probable kenkynnol of the old lordly line of Galloway and leaders of the proBalliol cause in the region. The MacDowells were probably the most substantial land-holding family east and west of the River Cree, and their network included Galloway's leading native kingroups. Although the grant to Malcolm was, therefore, speculative in that much of his earldom still lay in the hands of Edward Balliol and his allies, David had armed him with the coercive authority of a legal jurisdiction as a means to turn his titular lordship into a reality. 
Regality authority had been used very effectively by Thomas Randolph in Moray after 1312 and its application in Wigtown was an astute move by the Bruce leadership, who at Ayr in November 1341 included John Randolph, earl of Moray. ${ }^{88}$ The successful assertion of power by the Randolphs across territory where they possessed neither an inherited regional kinship network nor a dominant land-holding provided encouragement to Malcolm to push harder to reassert Bruce authority in Galloway. Malcolm had to win his earldom for himself but his dependence on delegated royal authority to maintain control bound him inseparably to the king. From his already established position in Carrick and Ayr and reinforced with his overarching jurisdictional franchise, Malcolm was intended to be a reliable bastion of Bruce power in western Galloway.

There is no evidence for an immediate effort by Malcolm to convert his title into a reality; it was not until 1344 that he was styled 'earl' in royal documents. After attending council at Aberdeen in February 1342, however, he perhaps joined a foray into eastern Galloway against Duncan MacDowell. ${ }^{89}$ By 18 June, he had rejoined David for a council-meeting at Restenneth and he was in his company intermittently thereafter as David moved between Dumbarton, Dunfermline and Lindores down to January $1343 .^{90}$ There were opportunities during this period for a campaign to consolidate gains made in the spring. Perhaps significantly, in May 1342 Godfrey Ross, a former pro-Balliol sheriff of Ayr, and Gilbert and Patrick McCulloch, leaders of that powerful Wigtownshire kindred, received compensation from Edward III for the loss of their lands. ${ }^{91}$ The following year, Michael and Thomas McCulloch, who had also lost lands in Galloway, likewise received a daily cash allowance for their maintenance. ${ }^{92}$ It is slim pickings through which to perceive how Malcolm advanced his authority, but this displacement of pro-Balliol men locally points to progress in $1342 / 3$.

Further hints of activity in the Galwegian military theatre are provided by property deals involving Malcolm and other figures prominent in the pro-Bruce recovery. Amongst business at the Restenneth council was an exchange by Malcolm of land at Mochrum in Wigtownshire for Cardoness in eastern Galloway, ${ }^{93}$ 
probably due to Patrick Dunbar, earl of March's rival claim to the former. Patrick's successor held Mochrum in July 1365, but the lands had been held in the 1310s by Edward Bruce and down to 1333 by Alexander Bruce, earl of Carrick. ${ }^{94}$ The Dunbar interest may have dated from the early $1200 \mathrm{~s}$, when there was a close connection between the Dunbars and the Galloways, ${ }^{95}$ but they had clearly lost possession before 1314 . Why either David, or perhaps Malcolm, felt the need to restore Patrick to his lost heritage at this juncture is unknown, given David's conspicuous failure to reward Patrick's support for his cause from 1335; it is possible that the earl's support in military operations against Balliol's Galloway powerbase was being bought.

A further offensive may have been launched in June 1343, when Malcolm attended a major political gathering at Ayr. ${ }^{96}$ Malcolm, however, can only be placed there on 6 and 30 June and it is possible that it was then that he commenced the steady pressure on the MacDowells which culminated in Duncan MacDowell's defection to David II in 1345. ${ }^{97}$ Evidence for Malcolm's activity in Wigtownshire, however, is otherwise slender but it seems that while he sought to break the native kindreds he positively courted the region's politically-influential monasteries. The loss of the cartularies of Glenluce, Soulseat and Whithorn has deprived us of the main record of religious benefaction on the part of Galloway's rulers, but sufficient evidence remains to reveal Malcolm's efforts to cultivate these institutions. Glenluce benefited substantially from his patronage, receiving from him what was effectively the erection of its barony jurisdiction into a regality and the gift of the ten merkland of Barns. ${ }^{98}$ These grants to Glenluce apart, however, the weight of Malcolm's religious patronage was directed towards institutions outside Galloway.

Further signs of favour can be seen in the good marriages secured for his daughters. Eva, who had probably attended court since David's return from France, withdrew from court sometime in 1342, whereupon she received a gift of 40 shillings from the king. Her withdrawal perhaps related to her impending marriage to John Ramsay, with whom she received a royal grant of Tannadice in Angus. ${ }^{99}$ Marjory, his eldest daughter, possibly David II's mistress in the early 1340 s, married the Lothian knight William of Fa' side, 
and received grants from David of crown properties near Clackmannan. ${ }^{100}$ His household servants, too, could expect advancement through association with this still-rising star. The clerk Robert of Dumbarton, who was probably Malcolm's secretary and who can be seen involved in the administration of the sheriffdom and castle of Dumbarton, served in David II's administration in the early 1340s as Clerk Register, and was further rewarded by Malcolm with a grant of land at Leadburn and Wester Hailes in Midlothian. ${ }^{101}$

Throughout this period of active royal favour and pursuit of his earldom, Malcolm was also consolidating his influence in Carrick and Ayr. In Ayr, he patronised the Dominican convent and before 1344 built a chapel there and endowed it with six merks annually from his own coffers. ${ }^{102}$ Two years later he replaced this cash payment with an annual rent of 100 shillings from properties near the burgh. ${ }^{103}$ His building of the chapel and endowment pro anima, for the souls of himself, parents, ancestors and successors, is suggestive of an intention to be buried there. The endowment given to the Dominicans was very substantial, for example equalling King Robert III's provision in 1405 for the soul of his eldest son in the parish church of Dundee. The scale of the patronage, construction of the chapel, and its probable intended mortuary function underline the importance of Ayr and Carrick to Malcolm throughout his career.

Further evidence of this importance to Malcolm can be seen in the continuing prominence in his following of men from Carrick and Kyle. Dumbarton and Lenzie, despite his earlier association with them, were of more secondary importance; the Lennox man, Finlay of Campsie, and the Dumbartonshire/ Renfrewshire knight Sir John Danielston, appear on the periphery of his retinue from the 1340s. ${ }^{104}$ His most trusted intimate was Sir Robert Wallace, his constable of Dumbarton from as early as 1328 and who remained in Malcolm's service throughout his career. ${ }^{105}$ Wallace was the most regular witness to Malcolm's acta and appears elsewhere as a supporting witness in his company. ${ }^{106}$ Robert's kinsman, Sir Duncan Wallace, lord of Sundrum and Dalmellington in Kyle, was another associate. ${ }^{107}$ Duncan's marriage to Eleanor Douglas, sister of William, $1^{\text {st }}$ earl of Douglas, 
and successively widow of Alexander Bruce, earl of Carrick, Sir John Sandilands and Sir James Towers of Dalry, brought him control of her terce lands in Galloway and Carrick amongst other properties. ${ }^{108}$ His links with the Flemings were emphasised in 1361 when he served as executor to the will of Countess Marjory, yet in 1373 he was a major beneficiary, in association with a group of former Fleming adherents, of some shadowy deals which enshrouded the dismemberment of the Fleming inheritance. ${ }^{109}$ Nicholas of Knockdolian, a southern Carrick knight, also featured prominently in Malcolm's following, and maintained his association under Malcolm's grandson Thomas. ${ }^{110}$ Together with his links to the Carrick family, kenkynnol of the old Carrick comital kindred, with the Kennedys of Dunure, the rising power in the earldom, and other lesser figures like Murdac son of Somerled, ${ }^{111}$ these men provided an enduring network of support for Malcolm in the southwest. Through their efforts, by June 1344 he could meaningfully use the title that had been granted two-and-a-half years earlier. ${ }^{112}$

The June 1344 Scone parliament where Malcolm commenced regular use of his title showed on the one hand his continued inclusion in David II's close circle of adherents but on the other provided a hint of renewed links with Robert Stewart. In the retrial of Malise, earl of Strathearn, for treason on account of his pre-1339 communing with Edward Balliol and his English allies that formed the main business of that assembly, Malcolm was part of David's 'packing' of the bench of jurors. ${ }^{113}$ Despite David's careful exclusion of the Steward and his associates from the panel, Malise was acquitted of treason but found guilty of having surrendered Strathearn to Balliol and so merited forfeiture. As Michael Penman has argued, if a charge of treason for making a submission to Edward Balliol was to be secured against Malise then other leading figures including Robert Stewart, Duncan of Fife, Patrick of Dunbar, close associates of the king like William Ramsay of Colluthie, Thomas Bisset of Upsettlington, John Maxwell of Caerlaverock and John Logie of Strathgartney, and possibly even Malcolm Fleming, could be exposed to a similar accusation. ${ }^{114}$ Awareness of that threat perhaps persuaded Malcolm that renewal of his Stewart links might in the long term be 
beneficial, and his inclusion with Robert and Patrick Dunbar as cautioners for the following of William Douglas of Liddesdale in the ending of the long-running feud between them and the followers of the late Alexander Ramsay of Dalhousie (which the king had helped to prolong) could signal that a rapprochement had been reached at Scone. ${ }^{115}$

Tensions between Malcolm and David might underlie events which unfolded in the aftermath of the parliament. Walter Bower, who took the core details of his story from the fourteenthcentury narrative of 'Fordoun's' anonymous source, relates how a man claiming to be the son of an unnamed Aberdeen burgess, who had been imprisoned in England for fourteen years, appeared that year. ${ }^{116}$ Once his ransom had been paid, the man produced what Bower describes as 'many tokens and clear evidence' to prove that he was actually Alexander Bruce, earl of Carrick, who was believed to have been killed in 1333. His claims are said to have won widespread popular belief and triggered unrest, which might point to grass-roots dissatisfaction with the ruling regime in areas from where Alexander Bruce and his father had drawn support. After meeting with David and unnamed magnates, the pretender fled to Carrick, claiming that he feared for his life at the hands of the men who controlled his heritage. Although no names are given, it would have been known widely that such men included Malcolm and several of his following, and Robert Stewart. David thereupon denounced him as an impostor and, once he was captured, handed him over to Fleming and Stewart, in whose presence he was hanged at Ayr in July 1344. ${ }^{117}$

Prima facie, this is a simple tale of attempted fraud and its consequences, but the coincidence of this pseudo-Alexander's appearance with a parliament where David had given notice of a rigorous challenge to his nephew's influence suggests deeper behind-the-scenes manoeuvres. Simply the suggestion that this pretender was in fact Alexander Bruce raised questions over the position of two leading figures, Malcolm from the perspective that the land from which he drew his military support and indeed his title had been Alexander's heritage but Robert even more seriously from the perspective of a threat to his position as next in line for the throne from a man who, although born illegitimate, was the closest 
male in terms of the 1315 tailzie which settled the succession. It is therefore possible that David had favoured this claimant before the widespread support for the pseudo-Alexander awakened him to the threat posed to his own position by a popular alternative Bruce heir. For Malcolm, it may have been a timely reminder of from whom his social elevation stemmed, to warn him of the risks of his flirtation with the Steward. Malcolm's dependence on this south Ayrshire nexus, with its strong associations with Edward Bruce, provides the context for his anxiety to end this challenge. The loss of most of the enrolled royal charters from 1344 makes it impossible to trace the movement of the key players in these events and perhaps misleadingly heightens a sense of estrangement between David and Malcolm, but there also seems to have been a hiatus in the summer of 1344 in the flow of royal patronage towards the men who formed Fleming's following.

Whatever the background to this disturbing episode, Malcolm was again in David's company and witnessing royal charters by early autumn 1344 . He was probably present with the king, the Steward and Maurice Murray, newly-created earl of Strathearn, at Mouswald in Annandale on 10 September and, together with a rush of new charters and confirmations to men holding lands in eastern Galloway and Annandale, this foray points to a conscious effort to restore relations and give reassurance to men whose position had been threatened in the preceding months. ${ }^{118}$ Amongst these grants was a confirmation of Malcolm's earldom. ${ }^{119}$ Further reassurance was perhaps provided by David's visit to Dumbarton on 17 October, but there is no evidence to place Malcolm in David's company again until April $1345 .{ }^{120}$ From Edinburgh David headed west to Dumbarton and thereafter spent most of the summer moving back and forward between the two centres accompanied by the Steward, John Randolph, Patrick Dunbar, Maurice Murray and Fleming. ${ }^{121}$ David was at Aberdeen on 4 November but it is not until 22 November at Elgin that Malcolm was certainly with him. ${ }^{122}$ The royal party, including Malcolm, returned to Dumbarton before 28 December and it is likely that David held his Christmas court there. ${ }^{123}$ Eighteen months on from the Scone parliament, Malcolm had been restored firmly to the inner circle of David's council. 
The king's assertion of his authority across 1344-5 had much to do with his quest for an heir of his own choosing but was also bound up in his desire to build a military following of his own. Down to early summer 1346 there are indications that this process was preparatory of a major military expedition into England led by the king under his own banner. Within Malcolm's regional sphere of influence, the issuing of crown charters and confirmations evident in autumn 1344 resumed, probably to tie associates more firmly into his service, but more importantly to reinforce David's personal authority over men who had recently renounced their allegiance to Edward Balliol. Foremost amongst such men were Dougal and Fergus McDowell, the first of whom received the lands of Senwick, Twynholm and Kelton, properties that had either pertained to Balliol's heritage or had been held by families who still adhered to the Balliol cause, while the latter received the constabulary of Kirkcudbright and a three-merkland for his support. ${ }^{124}$ More general support was sought through a royal charter which confirmed the traditional laws and liberties of Galloway. ${ }^{125}$ These grants, however, were concentrated in eastern Galloway outside the range of Malcolm's regality jurisdiction and within his earldom he was left to his own devices.

Malcolm returned to the south-west early in May 1346 when he made a new grant to his chapel in the Dominican church at Ayr. ${ }^{126}$ By 5 May he had returned to Dumbarton where he joined the king, Robert Stewart, John Randolph, Patrick of Dunbar and the chancellor. ${ }^{127}$ It was probably around this time that royal charters were received by Nicholas of Knockdolian in respect of lands near Girvan and by Robert of Dumbarton, confirming Malcolm's grant to him of land at Wester Hailes and Leadburn in Midlothian, rewarding two prominent members of Fleming's following. From Dumbarton, he probably accompanied David to Perth for a meeting of council which lasted until the end of May ${ }^{128}$ and by 27 August he was again in Dumbarton with the king, the Steward, Moray, March and the chancellor. Although there is no indication that he followed them to Edinburgh, he joined that same group at Stirling for a last council-meeting before the expedition into England. ${ }^{129}$

Early 1346 was, in retrospect, the summit of Malcolm's achievement. Years of loyal service, first as an administrative 
officer and personal guardian of the child king and queen, then as defender of the military base from which the Bruce cause staged its comeback after 1333, had won him a place at the heart of David's councils. Although overshadowed by the king's ambitious nephew and the glamorous military reputations of John Randolph and William Douglas, Malcolm's loyalty was the bedrock upon which the Bruce recovery was achieved. Recognition of his role in saving David II's crown had come with the award of an earldom for himself and his heirs, propelling him into the topmost echelon of Scottish noble society and cementing his status as one of David's intimate councillors. It also labelled him as David's man and bound his fortunes to those of the king. The outcome of the English campaign, on which David pinned his own hopes of consolidating political dominance in Scotland, would shape not only David's future but that of the men he had gathered around himself.

Continued in Part 2 below

\section{NoTES}

${ }^{1}$ See, for example, S Boardman, The Early Stewart Kings: Robert II and Robert III (East Linton, 1996) and ibid, The Campbells (Edinburgh, 2006); M Brown, The Black Douglases (East Linton, 1998); and essays by Boardman, Brown, Macdonald, MacQueen and Ross in S Boardman and A Ross (eds), The Exercise of Power in Medieval Scotland (Dublin, 2003). ${ }^{2}$ Compare, for example, discussion of the careers of Maurice Murray of Drumsargard, earl of Strathearn, or Thomas Stewart, earl of Angus, in M Penman, David II 1329-71 (East Linton, 2004) and R Nicholson, Scotland: the Later Middle Ages (Edinburgh, 1978).

${ }^{3}$ L Toorians, 'Twelfth-century Flemish Settlements in Scotland', in G G Simpson (ed), Scotland and the Low Countries 1124-1994 (East Linton, 1996), 1-14 at 4, 5-10.

${ }_{5}^{4}$ J B Paul (ed), The Scots Peerage, viii (Edinburgh, 1911), 520.

${ }^{5}$ The Records of the Parliaments of Scotland to 1707, K.M. Brown et al eds (St Andrews, 2007-2015), 1290/3/1. Date accessed: 6 January 2015; ibid, 1290/3/2. Date accessed: 6 January 2015. 
${ }^{6}$ People of Medieval Scotland http://db.poms.ac.uk/record/person/12826/\# ; RPS 1290/3/1 and RPS 1290/3/2. Date accessed 24 February 2017.

${ }^{7}$ Paul (ed), Scots Peerage, viii, 520.

${ }^{8}$ See, for example, the 'Genealogy of the Mackenzies', composed in 1669, in Genealogical Collections Concerning Families in Scotland Made by Walter Macfarlane 1750-1751, ed J T Clark, i (Scottish History Society, 1900), 54-69 at 57-8.

${ }_{9}^{9}$ Scots Peerage, viii, 520.

${ }^{10}$ E L G Stones and G G Simpson (eds), Edward I and the Throne of Scotland 1290-1296: an Edition of the Record Sources for the Great Cause, vol ii (Oxford, 1978), 342-3.

${ }^{11}$ G W S Barrow, Robert Bruce and the Community of the Realm of Scotland, $3^{\text {rd }}$ edition (Edinburgh, 1988), 43-4. For discussion of the agreement in the context of the Great cause, see also A A M Duncan, The Kingship of the Scots: Succession and Independence (Edinburgh, 2002), 184-5; A Beam, The Balliol Dynasty 1210-1364 (Edinburgh, 2008), 97 and M Penman, Robert the Bruce King of the Scots (London, 2014), 35. Beam refers to Sir Nicholas as 'Nicholas de Fleming of Biggar', presumably referring to his probable descent from the twelfth-century Flemish settler, Baldwin, but this style occurs in no surviving contemporary record. For the lineage descending from Baldwin, see G F Black, The Surnames of Scotland (New York, 1946), 74 and more recently the sequence recoverable via the prosopographical detail in POMS.

12 POMS http://db.poms.ac.uk/record/person/11359/\#

${ }_{13}^{13}$ Scots Peerage, viii, 520, 524.

${ }^{14}$ According to these accounts, Marjory was daughter of this implacable opponent of Edward I who was executed in September 1306: J T Clark (ed), Genealogical Collections Concerning Families in Scotland made by Walter Macfarlane, 1750-1751, vol ii (Scottish History Society, 1900), 316 (Fraser family); Barrow, Robert Bruce, 155-6.

${ }^{15}$ Registrum Magni Sigilli Regum Scotorum, i, 1306-1424, ed J M Thomson (Edinburgh, 1882), no.80 [hereafter RMS, i].

${ }^{16}$ For the annuity, uplifted from the rents of Holyrood Abbey's barony of Kerse in Stirlingshire, see Charter Chest of the Earldom of Wigtown, 1214-1681, ed F J Grant (Scottish Record Society, 1910), no.824. ${ }^{17}$ Registrum Monasterii de Passelet (Maitland Club, 1832), 237 [hereafter Paisley Registrum]. The approval of this charter by diocesan Official was 
dated 30 January 1318/9 Registrum Epsicopatus Glasguensis (Bannatyne Club, 1843), volume 1, no. 266 [hereafter Glasgow Registrum].

${ }^{18}$ See, for example, Cartularium Comitatus de Levenax (Maitland Club, 1833), 19 [hereafter Lennox Cartulary], where Sir James Stewart is the second witness after Malcolm to an act of Malcolm, earl of Lennox, issued ${ }_{19}^{\text {at Dumbarton in early December } 1330 .}$

${ }^{19}$ William Comyn, who became earl of Buchan by marriage c.1212, acquired Lenzie by grant of King William c. 1200 for the service of one knight; Regesta Regum Scottorum, ii, The Acts of William I, ed G W S Barrow (Edinburgh, 1971), no. 557 [hereafter $R R S$, ii]. His lands included Kirkintilloch, property in which he was in dispute over with the bishop of Glasgow in 1201/2; $R R S$, ii, no. 430. William was being styled 'lord of Lenzie and Kirkintilloch' in royal charters by 1203; NRS GD45/13/246. A Young, Robert the Bruce's Rivals: The Comyns, 1212-1314 (East Linton, 1997), 19-20.

${ }^{20}$ Registrum Monasterii S Marie de Cambuskenneth, ed W Fraser (Grampian Club, 1872), xxxi-xxxii. The act, drawn up in John Comyn II of Badenoch's 'open court' at Lenzie, was witnessed by 'Fergus Kennedy, our steward' and his brother, John Kennedy, amongst others.

${ }^{21}$ H L MacQueen, 'The Kin of Kennedy, "Kenkynnol" and the Common Law', in A Grant and K J Stringer (eds), Medieval Scotland: Crown, Lordship and Community (Edinburgh, 1993), 274-296 at 283. Calendar of Documents Relating to Scotland, ii, 1272-1307, ed J Bain (Edinburgh, 1884), nos 812, 832 (p.203). Sir Hugh Kennedy was restored to his lands on 7 September 1296 by mandate of Edward I of England; Rotuli Scotiae in Turri Londinensi et in Domo Capitulari Westmonasteriensi Asservati, eds D Macpherson and others, i (London, 1814), 29b [hereafter Rotuli Scotiae].

${ }^{22}$ Regesta Regum Scottorum, vi, The Acts of David II, ed B Webster (Edinburgh, 1982), no. 160 [hereafter $R R S$, vi]. It was regranted to Malcolm Fleming of Biggar and his wife, Christian, on 6 April 1362, under an entail; $R R S$, vi, no. 270. MacQueen, 'Kin of Kennedy', 283. ${ }^{23}$ Regesta Regum Scottorum, v, The Acts of Robert I, ed A A M Duncan (Edinburgh, 1988), 103 [hereafter RRS, v].

${ }_{25}^{24} R R S, \mathrm{v}$, no. 384.

${ }^{25} R M S, \mathrm{i}$, no. 81

${ }^{26} R R S$, v, no. 55 .

${ }^{27} R R S$, v, no.313. 
28 The Exchequer Rolls of Scotland, i, 1264-1359, eds J Stuart and G Burnett (Edinburgh, 1878), 257 [hereafter ER, i].

${ }^{29} R R S, \mathrm{v}, 112$.

30 ER, i, 257.

${ }^{31}$ Glasgow Registrum, no. 276. Malcolm was again involved in a property transaction involving Simon Lockhart, this time concerning the monks of Newbattle, when his seal was used in an agreement between Lockhart and the abbey dated 1 April 1339; Registrum S Marie de Neubotle (Bannatyne Club, 1849), no. 214 [hereafter Newbattle Registrum].

32 Lennox Cartulary, 23-4. The third witness to the charter is an otherwise unknown Hugh Fleming, knight. It is possible that this man is the enigmatic and unnamed son of Malcolm Fleming, for whose marriage in 1328/9 King Robert gave $£ 40: E R, \mathrm{i}, 216$. Hugh, however, was also a common name in a family of Flemings active in the southern part of the Lennox in the mid-thirteenth century: POMS

http://db.poms.ac.uk/record/person/4716/\#

33 Lennox Cartulary, 33, 52, 55, 58, 62, 63, 92, 95.

${ }^{34} R M S$, i, app. ii, no. 325 .

$35 E R, \mathrm{i}, 258-9 ; R R S, \mathrm{v}$, no.553.

${ }^{36} R R S, \mathrm{v}, 67$

37 Edward was styled 'lord of Galloway' in a charter issued at Dundee on 12 April 1312: RRS, v, no.19.

38 Penman, David II, 35.

39 He is referred to as David's 'alumnus' or foster-father in two royal charters of 1341 (RMS, i, app. i, no. 112; RRS, vi, no. 39 and in Walter Bower's fifteenth-century account of the events of May 1334 which was founded on an otherwise anonymous later fourteenth-century source: Walter Bower, Scotichronicon, ed D E R Watt and others (Aberdeen, 1996), vii, 83. Wyntoun makes no mention of Fleming's relationship with the boy David II. Marjory's status as 'nurse' to the Bruce heir is only stated explicitly in a petition to the pope in 1343 (Calendar of Entries in the Papal Registers Relating to Great Britain and Ireland: Petitions to the Pope, ed W H Bliss (London, 1896), 27).

40 See, for example, Charters of the Friars Preachers of Ayr (Ayr and Wigton Archaeological Association, 1881), nos 6, 15; Lennox Cartulary, $62,63,68,93$. The Knockdolians were probably members of the already extensive Kennedy kindred.

${ }^{41} E R, \mathrm{i}, 115,250$. 
${ }^{42} R R S, \mathrm{v}, 112$. For his accounts as steward of the king's house, see $E R, \mathrm{i}$, 248-260.

${ }^{43} E R, \mathrm{i}, 216$.

${ }_{45}^{4}$ See footnote 19 above.

${ }_{45}^{45}$ Paisley Registrum, 205-206.

${ }^{46}$ Chronicon Domini Walteri de Hemingburgh, ii (London, 1849), 308-9. For an expanded list of the leading men in the second battle, see The Anonimalle Chronicle 1307 to 1334, ed W R Childs and J Taylor (Cambridge, 1991), 165.

47 The Orygynale Cronykil of Scotland by Androw of Wyntoun, ed D Laing, ii (Edinburgh, 1872), 404: Wyntoun says that of the four castles and one peel holding out in the name of King David (the others being Kildrummy, Loch Doon, Loch Leven and Urquhart),

Dwnbrettane wes the pryncypalle

For thiddyrwart repayryd hale

The folk that yharnyd till lyve freely:

Schyr Malcolm Flemyng the worthy

Off that castelle wes capytane.

${ }_{49}^{48}$ Penman, David II, 49; Bower, Scotichronicon, vii, 83.

${ }_{50}^{49}$ Chron. Hemingburgh, ii, 310.

50 Atholl was styled 'Steward of Scotland' by late August 1333.

Nicholson, Edward III and the Scots, 148 note 6.

${ }_{51}^{51}$ Wyntoun, Orygynale Cronykil, ii, 407.

52 His kinsmen appear in the 1360 s with a Fleming connection related to the Lenzie/Lennox lands and a strong interest in western Menteith and Dumbarton involving a connection with Robert Erskine: see, for example, $R R S$, vi, no. 310, where John Lyle witnesses a confirmation of the sale of Cassillis in Carrick by the Montgomeries to John Kennedy; no. 327, where Lyle witnesses a property exchange involving Robert Erskine and Strathgartney; no. 335, where he witnessed an act of Thomas Fleming.

${ }_{54}$ Bower, Scotichronicon, vii, 97.

${ }_{55}^{54}$ Wyntoun, Orygynale Cronykil, ii, 412-3.

${ }^{55}$ See, for example, S Boardman, The Early Stewart Kings: Robert II and Robert III 1371-1406 (East Linton, 1996), 4-5.

${ }^{56}$ Boardman, Early Stewart Kings, 4 and note 13. Boardman notes that 'Fordun's annals display a consistent personal hostility towards the Steward' and that they showed little interest in west and south-west Scotland. An original composition date before 1363 also places his 
writing in the context of hostility between David II and his nephew and represents a strongly court-centred narrative of events.

${ }_{58}^{57}$ Wyntoun, Orygynale Cronykil, ii, 408; Bower, Scotichronicon, vii, 97. ${ }^{58} E R, \mathrm{i}, 184,190,196$.

59 I A MacInnes, "“To be annexed forever to the English crown": The English occupation of Southern Scotland, c.1334-1337', in A King and D Simpkin (eds), England and Scotland at War, c.1296-c.1513 (Brill, 2012), 183-202 at 194 and sources cited in note 50; Penman, David II, 58-61.

${ }^{60}$ The Records of the Parliaments of Scotland to 1707, eds K M Brown et al (St Andrews, 2007-2015), 1334/1. Date accessed: 24 February 2015.

61 Calendar of Documents Relating to Scotland, iii, 1307-1357, ed J Bain (London, 1887), nos 1099, 1100 [hereafter CDS, iii]. R Nicholson, Edward III and the Scots. The Formative Years of a Military Career 1327-1335 (Oxford, 1965), 150.

${ }_{63}^{62} C D S$, iii, no. 1108 .

${ }^{63}$ For discussion, see S Boardman, The Campbells 1250-1513 (Edinburgh, 2006), 58-9.

${ }^{64}$ Wyntoun, Orygynale Cronykil, ii, 414-5; Bower, Scotichronicon, vii, 103,105 .

${ }^{65}$ Wyntoun, Orygynale Cronykil, ii, 416; Bower, Scotichronicon, vii, 105, 107.

${ }^{66}$ Oeuvres de Froissart: Chroniques, ii, 1322-1339 (Brussels, 1867), 328 and following. See also Penman, David II, 52-3.

${ }_{67}^{67}$ Wyntoun, Orygynale Cronykil, ii, 416; Bower, Scotichronicon, vii, 107. ${ }_{68}^{68}$ Bower, Scotichronicon, vii, 141.

${ }^{69}$ We can place him at Newbattle Abbey in Midlothian on 1 April 1339 when his seal and that of Thomas Charteris, the chancellor, were used to add greater weight to a settlement between Simon Lockhart and the monastery; Newbattle Registrum, no. 214. That joint action with Charteris suggests that he still held a role in the administration of the kingdom but there is no further evidence for the nature of that role.

${ }_{71}^{70}$ Penman, David II, 78-9 and note 9.

${ }^{71}$ Wyntoun, Orygynale Cronykil, ii, 416; Bower, Scotichronicon, vii, 107.

${ }^{72}$ Wyntoun, Orygynale Cronykil, ii, 416:

The yhynge Stwart off Scotland then

In mekill hy gadderyde his men; And thame that lay at Dwnbertane, All halyly wyth thaim have their tane: Thai ware the floure off thare menyhé. 
${ }^{73}$ For discussion of this issue see S Boardman, 'Chronicle propaganda in fourteenth-century Scotland: Robert the Steward, John of Fordun and the "Anonymous Chronicle"', Scottish Historical Review, 76 (1997), 23-43. ${ }_{75}^{74} R S$, , vi, no. 18 .

${ }^{75} R R S$, vi, nos $25,27,30,31,33,35,483$, where Malcolm is a witness to David's charters issued during this period.

${ }_{77}^{76} R S$, vi, no. 30.

${ }^{77} R R S$, v, no. 290, where Robert I granted the patronage of Kilmaronock to Cambuskenneth Abbey. This may have been a re-grant as letters patent to John, bishop of Glasgow, authorising him to appropriate the parish church to the abbey, were issued between October 1323 and November 1325, when he granted the church in proprios usus: RRS, v, no. 504; Registrum Monasterii S Marie de Cambuskenneth (Grampian Club, 1872), no. 146. There is no evidence to support the statement by Cynthia Neville that the patronage of Kilmaronock pertained to the earls of Lennox: C J Neville, Native Lordship in Medieval Scotland: The Earldoms of Strathearn and Lennox, c.1140-1365 (Dublin, 2005), 157 note 66 [where the name is given erroneously as 'Kilmarnock'].

${ }_{79}^{78}$ Glasgow Registrum, no.308.

${ }^{79} R R S$, vi, no. 31.

${ }^{80} R M S$, i, app. i, no. $112 ; R R S$, vi, 505

${ }^{81}$ Penman, David II, 80 .

${ }_{83}^{82} R R S$, vi, nos 33-37.

${ }_{84}^{83} R S$, vi, nos 39,40

${ }_{85}^{84} R R S$, vi, no.39.

${ }^{85}$ For Malcolm at Aberdeen, see RRS, vi, nos 45, 47. For the business at Aberdeen and the collusion of Douglas and the Steward, see Penman, David II, 86-88.

${ }^{86}$ See, 'The forfeited estates of the Black Douglases' in P.G.B.McNeill and H.L.MacQueen (eds), Atlas of Scottish History to 1707 (Edinburgh, 1996), 447.

${ }^{87}$ The kin structures upon which the power of the lords of Galloway was based is discussed in R D Oram, 'A family business? Colonisation and settlement in twelfth- and thirteenth-century Galloway', Scottish Historical Review, lxxii (1993).

${ }^{88}$ The exact date of Moray's release from captivity in England has been much debated [see Penman, David II, 75 and note 92, where an early 1342 date is proposed], but this charter and a safe conduct issued on 22 
February 1341/2 for his passage through England to France and return [CDS, iv, no.1376] point strongly to a release-date in 1341.

89 R D Oram, 'Dervorgilla, the Balliols and Buittle', Transactions of the Dumfriesshire and Galloway Natural History and Antiquarian Society, lxxiii (1999), 165-181 at 179-80.

${ }_{91}^{9} R R S$, vi, nos 52, 53, 54, 59, 60, 61, 62, 63, 64 .

91 CDS, iii, nos 1390-1392.

92 CDS, iii, no. 1412.

93 RRS, vi, no. 52. The land he received, of which only the '...rnes' at the end of the name is legible in the surviving text, was described as 'pertaining to us by reason of forfeiture'. Cardoness had been held by a prominent, Balliol-supporting tenant family in the 1290s (see R D Oram, The Lordship of Galloway (Edinburgh, 2000), 230). It is mistakenly identified as the Rhins in Wigtownshire in Penman, David II, 95.

${ }^{94} R R S$, vi, no. 506. Edward Bruce granted an annual render of six stones of beeswax annually from Cruggleton and Mochrum to Whithorn Priory; $R M S$, i, app. i, no. 20. It was amongst properties granted to Edward's bastard son, Alexander Bruce in c.1328-9 and which reverted to the crown on Alexander's death in 1333; RMS, i, app. ii, no. 623. Patrick is named explicitly as having held possession in a charter of 25 July 1368, which confirmed the lands of Cumnock, Blantyre, Glenken and Mochrum in the hands of George Dunbar, earl of March: RMS, i, no. 291.

95 R D Oram, Alexander II, King of Scots, 1214-1249 (Edinburgh, 2012), 161-2.

96 RRS, vi, nos 71-4, where David and his council were in Ayr between 6 and 30 June.

97 RRS, vi, nos 71, 74; The Anonimalle Chronicle 1333 to 1381, ed. V.H.Galbraith (Manchester, 1927), s.a. 1345.

98 Wigtownshire Charters, ed R C Reid (Scottish History Society, 1960), no. 37, where both charters survive only within a general confirmation in the name of King James II, dated 31 May 1441.

${ }_{109}^{99} \mathrm{ER}, \mathrm{i}, 509,589$.

100 Penman, David II, 83; APS, i, appendix, 168. In the 1342 Exchequer accounts, payment of $£ 196 \mathrm{~s} 8 \mathrm{~d}$ to her 'for the debt in which the king is beholden to her' was recorded: $E R, \mathrm{i}, 506$. She received a gift of woollen cloth worth $£ 413 \mathrm{~s} 4 \mathrm{~d}$ in the same account: $E R, \mathrm{i}, 509$. There is also reference to a payment of 20 shillings to one Henry of Kinghorn, by the king's mandate, authorised by the seal of Lady Marjory Fleming, which 
suggests a very close relationship between David and Malcolm's daughter: $E R$, i, 511.

${ }^{101} R M S$, i, app. ii, no. 1067. For outline of Robert's career, see $R R S$, vi, 11-12. He is discussed also in; A A M Duncan, 'The Regnal Year of David II', SHR, lxviii (1989), 105-19.

${ }_{103}^{102}$ Ayr Friars Preachers Charters, no. 8.

103 Ayr Friars Preachers Charters, no. 6. This charter, granted by Malcolm as earl, is wrongly dated to 3 May 1336. His presence at Dumbarton on 5 and 6 May (see $R R S$, vi, nos 101, 102) strengthens the probability that the gift was made as he travelled north from Wigtown.

${ }^{104}$ For Finlay of Campsie, see Lennox Cartulary, 58, 62, 92, 95. Both Finlay of Campsie and John Danielston witness Ayr Friars Preachers Charters, no. 15. Danielston was the principal witness to Malcom's charter of lands in Lennox to Andrew Cunninghame, Lennox Cartulary, 67-8.

${ }^{105}$ Lennox Cartulary, 62, 63, 68; Ayr Friars Preachers Charters, nos 6, 15; ER, i, 115, 250, 257.

106 See, for example, Ayr Friars Preachers Charters, nos 6, 15; Lennox Cartulary, 62, 63, 68.

${ }_{107} R M S$, i, no. 465.

108 RMS, i, nos 358, 464.

109 Registrum Honoris de Morton, ii, (Bannatyne Club, 1853), no. 79; RMS, i, no. 464.

110 Ayr Friars Preachers Charters, no. 15; RRS, vi, no. 128; Charters of the Abbey of Crossraguel, i (Edinburgh, 1886), no. 20 [hereafter Crossraguel Charters].

${ }^{111}$ For a discussion of these families, see H L MacQueen, 'The Kin of Kennedy, 'Kenkynnol' and the Common Law', in A Grant and K J Stringer (eds), Medieval Scotland: Crown, Lordship and Community (Edinburgh, 1993), 275-96. Gilbert of Carrick witnessed charters with Malcolm in the Lennox (Lennox Cartulary, 58, 92) where around 1342 and with subsequent confirmations into the 1350s he received a crown grant of Buchanan (RMS, i, app. ii, nos 876, 986, 1279). Early in 1342 he also received life-rent of the coronership between the rivers Ayr and Doon, i.e. within Kyle Regis, $R M S$, i, app. ii, no. 844. In the same period he was one of a group of Carrick men who received grants of land from the king in the Dee and Ken valleys in central Galloway. Gilbert's acquisition of Balliol's lordship of Kenmure, granted apparently in 1342 and confirmed in 1343, was the biggest single award made in that district, 
$R M S$, i, app. ii, nos $831,894,1100$. He was clearly not simply dependent on his association with Malcolm Fleming for political and social advancement. Murdac witnesses Ayr Friars Preachers Charters, no. 15. For his Carrick lands in the 1360s, see $R M S$, i, no. 135; app. ii, no. 1378.

${ }^{112} \mathrm{He}$ is styled so for the first time in a surviving record in the rolls of the Scone parliament of June 1344 (see RPS, 1344/1-7).

${ }_{113}^{11}$ Penman, David II, 107.

114 Penman, David II, 107-8.

115 RPS 1344/7; Penman, David II, 109.

116 Bower, Scotichronicon, vii, 157-9.

117 There is no evidence that places David, Malcolm and Robert in Ayr in July 1344, but it was on 6 July 1344 at Glasgow that Malcolm granted property outside the burgh to his chapel in the Dominican friary there, Ayr Friars Preachers Charters, no. 8.

${ }^{118} R R S$, vi, no. 81; RMS, i, app. ii, nos 894 (confirmation of Gilbert Carrick's charter of Kenmure), 903 (grant to the Mar knight, Laurence Gillibrand, of Southwick), 910 (grant to John Crawford of the keepership of the lands and forest of Glenken), 912-4 (settlement of the headship of kin of three Galloway and Carrick kindreds), 915 (grant of the customs of the sheriffdom of Dumfries to John Randolph, earl of Moray), 928 (confirmation to Robert Wallace of his Ayrshire lands), 929 (grant to Malcolm Danielston of 'Glencharry' in Ayrshire), 930 (grant to Nicholas Stirling of Stockerton in Dumfriesshire), 937 (charter to Alan Stewart of Darnley of the lands of Corsewall, 'Drochdreg' and part of Glengyre in the northern part of the Rhins of Galloway).

${ }_{119} R M S$, i, app. ii, no. 927.

${ }_{120}^{120} R R S$, vi, no. 89.

${ }^{121} R R S$, vi, nos 93, 94, 95, 98; RMS, i, app. i, no. 120; 'Miscellaneous

Charters, 1315-1401, from transcripts in the collection of the late Sir William Fraser', Miscellany of the Scottish History Society (Edinburgh, 1933), no. 9, dated at Dumbarton 10 July 1345.

${ }_{122}^{122} R R S$, vi, nos 98,$99 ; R M S$, i, app. i, no. 121.

${ }^{123} R R S$, vi, 100.

${ }^{124} R M S$, i, app. ii, nos 1006, 1007.

$125 R M S$, i, app. ii, no. 1012; Oram, Lordship of Galloway, 145.

${ }_{127}^{12}$ Ayr Friars Preachers Charters, no. 6. For dating, see above note 91.

$127 R R S$, vi, nos $101,102$.

${ }^{128} R R S$, vi, nos 103, 104. In addition to the core group of the Steward, earls of Moray, March, Strathearn and Wigtown, and the chancellor, 
David Hay the Constable joined the witnesses to the latter charter, his presence not only being facilitated by the proximity of the gathering to his lands at Erroll but also necessary for the likely military nature of the main discussions.

${ }^{129} R R S$, vi, nos 106-108. The king gathered his host from Scotland north of the Forth at Perth, where William, earl of Ross, had his men murder Ranald mac Ruairidh at Elcho nunnery east of the burgh; Wyntoun, Orygynale Cronykil, ii, 472. From there he marched south, presumably gathering additional contingents on the way and perhaps rendezvousing with Malcolm at Stirling. 